\title{
The Academic Library Impact on Student Persistence
}

\section{Mark Emmons and Frances C. Wilkinson}

\begin{abstract}
What impact does the academic library have on student persistence? This study explores the relationship between traditional library input and output measures of staff, collections, use, and services with fall-to-fall retention and six-year graduation rates at Association of Research Libraries member libraries. When controlling for race/ethnicity and socioeconomic status, a linear regression finds that a change in the ratio of library professional staff to students predicts a statistically significant positive relationship with both retention and graduation rates.
\end{abstract}

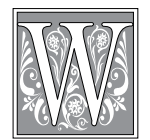

hat impact does the academic library have on student success? Based on our years of experience as academic librarians and reading the library literature, we had a sense that the vast majority of the published library research literature emphasizes input/output measures and program evaluation rather than library impact, that the importance of the library to the campus is often assumed, and that very little is published on the library's contributions to institutional goals.

Powell ${ }^{1}$ and Gratch-Lindauer ${ }^{2}$ each conducted literature reviews that confirmed our experiences. Powell reviewed the research literature on the impact that student use of the academic library has on academic performance. He found that few studies focus on impact, with most focusing on input and output or outcome measures. He cited impact studies that correlate academic library use and library skills with lower attrition rates and stu- dent persistence, higher grades and GRE scores, and savings in faculty time. ${ }^{3}$

Six years later, Gratch-Lindauer found little had changed with the majority of research "measuring inputs, processes, and outputs. However, almost none of these publications provide measures or methods for assessing the impact of academic libraries on campuswide educational outcomes." ${ }^{4}$ The main purpose of Gratch-Lindauer's literature review was to make a case for assessing a library's impact instead of making simple input and output measures and to uncover valued institutional outcomes in the areas of infrastructure, access, institutional viability, librarian teaching effectiveness and scholarly productivity, and impact on learning outcomes. ${ }^{5}$

Powell and Gratch-Lindauer were forerunners of a larger movement in academic libraries to find different ways of measuring library success. In the 1990s, librarians began to call for measures that reflected more than just input/output measures, 
such as number of volumes held, items circulated, and questions asked. National organizations such as the Association of Research Libraries (ARL) and the Association of College \& Research Libraries (ACRL) began to create measures that focused on outcomes. Accrediting agencies followed suit with standards requiring outcomes from libraries. The common theme behind all of these initiatives was a call for accountability.

The ARL commissioned at least two studies. Smith advised that libraries replace input/output measures with student learning outcomes. He recommended instead basing research on student-centered processes such as information literacy and student research. ${ }^{6}$ Fraser, McClure, and Leahy analyzed discussion forums, conducted site visits, reviewed accreditation standards, and surveyed ARL library directors to develop a framework for assessing library and institutional outcomes. They developed a model designed to tie library activities to campus vision, mission, and goals along with a set of questions to ask about resources, capacity, and outcomes. Measures were embedded in the model but not explicitly defined. Instead, the authors emphasized paying attention to local needs when devising measures. ${ }^{7}$

Weiner recognized the same need for outcome measures. Her interest was seeing how well traditional input-based measures translated to new outcomebased measures. Comparing resources as an input measure to services as an outcome measure, she found statistically significant correlations for the ARL index (which combines the input measures) and the number of reference transactions, group presentations, and attendees at presentations. ${ }^{8}$

Though these studies are interesting, they still make the library the focus of the investigation. We wanted to make a case that speaks not only to librarians and library administrators, but to campus administrators as well, so we focused on measures of interest to universities across the country. The ASHE Higher Education Report provides a list of 14 indicators that have been used in studies of student success in higher education (they, in turn, adapted the list from an earlier compilation by the American Association of Community Colleges). Indicators include student goal attainment, course retention and success, success in subsequent coursework, fall-to-fall persistence, time to degree, degree completion, graduate school enrollment and employment, transfer rate and success, employer assessment of students, academic value added (knowledge, skills), student satisfaction, student professional growth and development, student involvement, and

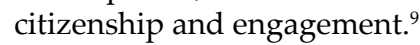

We determined that fall-to-fall persistence, better known as retention, and degree completion, most commonly called graduation, were the two measures we would use. The data were readily available because persistence is among the most used measure of student success and would therefore speak to librarians and administrators. So our initial question on what impact the academic library would have on student success changed with our definition of student success as persistence. We now ask: What impact does the academic library have on student persistence? Specifically: What impact does the academic library have on student retention? What impact does the academic library have on student graduation rates?

\section{Literature Review}

The library literature offers very few studies that examine the relationship between the academic library and retention or graduation. Most impact studies attempt to measure library outcomes other than retention and graduation. Two studies by Ethelene Whitmire serve as examples. She was interested in measures of student success. Whitmire analyzed factors that influence the development of critical thinking skills in undergraduates. She used the I-E-O model developed by Alexander W. 
Astin focusing on inputs, environment, and outcome and the quality of effort theory proposed by C. Robert Pace. Using student background characteristics as the input and college experiences such as library use as the environment, she found (among other nonlibrary factors) that "students engaged in more focused library activities reported a significant impact on their critical thinking development." 10 Whitmire expanded her study, finding that focused library activities had a significant impact on the development of critical thinking with research that looked more deeply at the types of library use. She found that libraries with greater resources had a significant impact on students' self-reported gains in critical thinking. ${ }^{11}$ These are but two examples of a small set of research analyzing the impact the library has on campus, making the case that the library is important to institutional goals. Most studies that investigate library impact are like the two studies by Whitmire: They look at measures that might indirectly influence student persistence, but they do not attempt to make direct assessments.

Recently, one study did take a stab at investigating the relationship of the library to retention. Mezick correlated traditional library input and output measures of expenditures, materials, and salaries. She found moderate correlations with student retention. The results are intriguing but are weakened by the fact that her study does not control for any nonlibrary factors. Still, the correlations are encouraging, indicating that there is a relationship between library measures and student persistence. ${ }^{12}$

With a paucity of research in the library literature, we turned to the broader educational literature. Here we found countless studies that addressed issues of student persistence. Perhaps the most comprehensive and most cited is the study by Alexander Astin, where he updates an earlier study with a completely new examination of how students change and develop in college and the factors that help them persist and graduate. Based on a thorough review of the literature, he identified 135 institutional measures and 57 student measures that influence a student's development in the areas of politics; personality and self-concept; attitudes, values, and beliefs; academic and cognitive development; career development; and satisfaction with college. He conducted a statistical correlation analysis to see which factors are the most significant. He also addressed institutional resources that impact student success. Astin found that the following factors were particularly significant: peer group, SES (especially for completion), faculty orientation (a research orientation has negative effect and a student orientation has positive effect), pedagogy (see pages 423-24 for a large list), diversity, student faculty ratio, financial aid, and living on campus. Library is not considered as a factor. Astin's division of measures into student and institutional factors is fairly typical. ${ }^{13}$

Significant student variables uncovered by more than one researcher include race (Astin ${ }^{14}$; Porter ${ }^{15}$; Murtaugh, Burns, \& Schuster ${ }^{16}$; Carey ${ }^{17}$; Strauss \& Volkwein ${ }^{18}$ ), SES (Astin ${ }^{19}$; Porter $^{20}$; Carey ${ }^{21}$; Habley \& McClanahan ${ }^{22}$ ), and gender (Murtaugh, Burns, \& Schuster ${ }^{23}$; Carey $^{24}$ ) and high school quality (Astin ${ }^{25}$; Adelman ${ }^{26}$ ), GPA and/or test scores (Astin ${ }^{27}$; Cabrera, Nora, \& Castaneda ${ }^{28}$; Murtaugh, Burns, \& Schuster ${ }^{29}$; Carey $^{30}$ ), job demands (Astin $^{31}$; Habley \& McClanahan $\left.{ }^{32}\right)$, student interactions with faculty (Astin ${ }^{33}$; Carey ${ }^{34}$; Habley \& McClanahan ${ }^{35}$; Strauss \& Volkwein $^{36}$ ) and the general idea of student institution fit or student engagement (Tinto ${ }^{37}$; Habley \& McClanahan ${ }^{38}$ ).

Significant institutional variables uncovered by more than one researcher include financial resources (Carey ${ }^{39}$; Pike, Smart, Kuh, \& Hayek $^{40}$ ), financial aid (Porter $^{41}$; Habley \& McClanahan ${ }^{42}$; Strauss \& Volkwein ${ }^{43}$ ), type of institution (Porter ${ }^{44}$; Adelman $^{45}$ ), and degree programs (As$\operatorname{tin}^{46}$; Carey $^{47}$ ).

Our interest is in student and institutional factors that make a difference once 
students are on campus and variables that are easily quantifiable. The variables most consistently cited as factors in the literature are race, SES, and gender. In fact, race and gender are factors that are often featured as primary variables of interest in research studies. Faye Carter reviews the literature that explores the reasons for the achievement gap between ethnic minority and ethnic majority students in college and its applicability to persistence. ${ }^{48}$ Titus conducted a statistical analysis on how the financial aspects of a college impact the graduation rates of low SES students. He found positive influences for a number of variables, including total educational expenditure per student and tuition revenue as a percentage of total revenue. These are critical variables, as Titus also noted that low SES students are disproportionally represented in institutions with lower levels of financial resources. ${ }^{49}$ While it might be possible to control for other factors, for the sake of parsimony and expedience, we will limit ourselves to these control factors. Our final research question is: Controlling for race, ethnicity, and gender:

1. Is there a relationship between academic library staff, collections, use, and services and student fall-to-fall persistence?

2. Is there a relationship between academic library staff, collections, use, and services and student degree completion?

\section{Research Methods \\ Sample}

The units of study in our sample are colleges and universities. We selected a sample of U.S. academic libraries from the Association of Research Libraries (ARL). ARL members consist of libraries with “distinctive research-oriented collections and resources of national significance." 50 The majority of members are academic libraries whose parent institutions are classified as high or very high by the Carnegie Classification of Institutions of Higher Education. The remaining libraries consist of a select group of public librar- ies. We excluded the public libraries and the Canadian academic libraries, leaving us a sample of 99 U.S. academic libraries. The sample consists of the colleges and universities where the ARL member libraries reside.

\section{Variables}

The data set that we examined was drawn from the 2005-2006 Annual Survey of ARL Statistics compiled by the Association of Research Libraries (ARL) ${ }^{51}$ and from the Integrated Postsecondary Education Data System (IPEDS) of the National Center for Education Statistics (NCES). ${ }^{52}$ ARL provided data on library staff, collections, use, and services. The variables that indicate staff include total wages paid and the number of professional staff per student-we derived this variable by dividing the total number of professional library staff by the number of full-time undergraduate and graduate students. The variables that indicate collections include total number of volumes, volumes added during the past year, and total expenditures for collections. The variable that indicates use is initial circulation. The variables that indicate services include number of reference questions asked and percent of students receiving instruction - we derived this variable by dividing the total number of students reached by library instructors by the number of full-time undergraduate and graduate students. There were missing cases for circulation, reference, and instruction; therefore, we replaced the missing values with the series mean. We created the perstudent statistics for professional staff and students receiving instruction by dividing the raw numbers for these variables by total FTE full-time student enrollment to reflect the library's reach.

IPEDS provided 2006 data on the dependent variables of retention and graduation and the control variables of gender, race/ethnicity, and percentage of students receiving need-based financial aid as a proxy for socioeconomic status (SES). The indicator for retention reflects 
2005 fall-to-fall persistence between first and second year by students. The indicator for graduation is the percentage of students who started college in 2000 and graduated within six years. Gender is indicated by male and female. Race/ ethnicity is indicated by Asian American, Black, Hispanic, American Indian, and White. The indicator for SES is percentage of students receiving need-based financial aid.

\section{Data Analysis}

We analyzed the relationship between the dependent variables of retention (RET) and graduation (GRAD) and the independent variables of staff (PROFPCT and WAGETOT), collections (VOLTOT, VOLADD, and EXPTOT), use (CIRC), and services (REF and CLASSPCT), controlling for gender (MALE and FEMALE), race/ethnicity (ASIAN, BLACK, HISPANIC, INDIAN, and WHITE), and SES
(FINAID). See Appendix for a codebook that includes a complete list of variables with their descriptions.

We performed standard descriptive statistical analyses. We computed univariate (single variable) statistics for all variables. We displayed relationships between each pair of variables in a scatterplot and performed a regression analysis of each independent and control variable on each dependent variable. We transformed the data to fit a linear regression model to the transformed data to compare the different models. We examined and removed atypical data and refit the model.

\section{Findings}

Retention and graduation rates vary widely. Retention is the percentage of fulltime students who were enrolled during the 2005 fall semester and returned in the fall of 2006. The mean and median for re-

\begin{tabular}{|c|c|c|c|}
\hline Descripti & tatistics & $\begin{array}{c}\text { TABLE } 1 \\
\text { or Retention and Graduation } \\
\text { Institutions }\end{array}$ & for a Sample of 99 ARL \\
\hline & & $\begin{array}{l}\text { Fall } 2005 \text { Full-Time Cohort 3rd } \\
\text { Semester Retention Rate }\end{array}$ & $\begin{array}{c}\text { Fall } 2000 \text { Full-Time Cohort } \\
\text { 6-Year Graduation Rate }\end{array}$ \\
\hline $\mathrm{N}$ & Valid & 98 & 99 \\
\hline & Missing & 1 & 0 \\
\hline Mean & & 88.79 & 73.09 \\
\hline Median & & 90.00 & 74.00 \\
\hline Mode & & 96.00 & 59.00 \\
\hline Std. Deviati & & 7.17 & 15.30 \\
\hline Skewness & & -.64 & -.34 \\
\hline Std. Error of & ewness & .24 & .24 \\
\hline Kurtosis & & -.28 & -.62 \\
\hline Std. Error of & irtosis & .48 & .48 \\
\hline Range & & 31.00 & 62.00 \\
\hline Minimum & & 68.00 & 36.00 \\
\hline Maximum & & 99.00 & 98.00 \\
\hline Percentiles & 25 & 84.00 & 62.00 \\
\hline & 50 & 90.00 & 74.00 \\
\hline & 75 & 95.00 & 85.00 \\
\hline
\end{tabular}


tention are both high at 88.79 percent and 90.00 percent respectively; however, the range is 31 with a minimum of 68 percent. We removed one case that was missing the data for retention. Graduation reflects the percentage of full-time students who started college in the fall of 2000 and had graduated within six years by fall of 2006 . Graduation rates are lower with both the mean and median at approximately 74 percent. The range is much higher at 62 with a minimum of 36 percent and a maximum of 99 percent. See table 1 for details of retention and graduation.

ARL libraries turned out to be a disparate group. Though we had anticipated that the libraries would be mostly similar with a few outstanding exceptions, the descriptive statistics revealed extreme differ- ences among members. These differences extended across staff, collections, use, and services. For example, the mean number of staff is 101 with a standard deviation of 66.71. The median is 88 , with a minimum of 36 and a maximum of 554, for a range of 518. This range is reflected in a huge kurtosis of 21.87; this kurtosis number indicates an upward deviation from the standard bell curve due to extreme cases. The same is true of wages. The mean total salaries and wages is $\$ 11,645,994.24$ with a standard deviation of $\$ 7,598,013.39$. The median is $\$ 9,539,578.00$, with a minimum of $\$ 4,440,988.00$ and a maximum of $\$ 58,047,311.00$, for a range of $\$ 53,606,323.00$. This range is reflected in a large kurtosis of 13.88 . The differences continue for collections. The mean

\begin{tabular}{|c|c|c|c|c|c|c|}
\hline \multicolumn{7}{|c|}{$\begin{array}{c}\text { TABLE } 2 \\
\begin{array}{c}\text { Descriptive Statistics for Staff, Wages, Total and Added Volumes, and Expenditures } \\
\text { for a Sample of 99 ARL Libraries }\end{array}\end{array}$} \\
\hline & & $\begin{array}{c}\text { Professional } \\
\text { Staff (FTE) }\end{array}$ & $\begin{array}{c}\text { Total Salaries \& } \\
\text { Wages }\end{array}$ & $\begin{array}{c}\text { Volumes In } \\
\text { Library }\end{array}$ & $\begin{array}{l}\text { Volumes } \\
\text { Added }\end{array}$ & $\begin{array}{c}\text { Expenditure on } \\
\text { Total Library } \\
\text { Materials }\end{array}$ \\
\hline \multirow[t]{2}{*}{$\mathrm{N}$} & Valid & 99 & 99 & 99 & 99 & 99 \\
\hline & Missing & 0 & 0 & 0 & 0 & 0 \\
\hline Mean & & 100.99 & $11,645,994.24$ & $4,240,929.47$ & $82,198.64$ & $10,315,796.52$ \\
\hline Median & & 88.00 & $9,539,578.00$ & $3,407,167.00$ & $67,393.00$ & $9,271,776.00$ \\
\hline Mode & & $51^{\mathrm{a}}$ & $4,440,988^{\mathrm{a}}$ & $2,056,928^{\mathrm{a}}$ & $26,287^{\mathrm{a}}$ & $3,411,656^{\mathrm{a}}$ \\
\hline Std. Deviation & & 66.71 & $7,598,013.39$ & $2,405,886.10$ & $48,880.47$ & $4,709,940.40$ \\
\hline Skewness & & 3.84 & 3.01 & 2.21 & 1.73 & 2.08 \\
\hline $\begin{array}{l}\text { Std. Error of } \\
\text { Skewness }\end{array}$ & & .243 & .24 & .24 & .24 & .24 \\
\hline Kurtosis & & 21.87 & 13.88 & 5.98 & 3.78 & 7.11 \\
\hline $\begin{array}{l}\text { Std. Error of } \\
\text { Kurtosis }\end{array}$ & & .48 & .48 & .48 & .48 & .48 \\
\hline Range & & 518 & $53,606,323$ & $13,769,642$ & 266,371 & $30,501,899$ \\
\hline Minimum & & 36 & $4,440,988$ & $2,056,928$ & 26,287 & $3,411,656$ \\
\hline Maximum & & 554 & $58,047,311$ & $15,826,570$ & 292,658 & $33,913,555$ \\
\hline \multirow[t]{3}{*}{ Percentiles } & 25 & 62.00 & $6,921,185.00$ & $2,704,986.00$ & $46,823.00$ & $7,371,492.00$ \\
\hline & 50 & 88.00 & $9,539,578.00$ & $3,407,167.00$ & $67,393.00$ & $9,271,776.00$ \\
\hline & 75 & 118.00 & $13,570,569.00$ & $4,909,264.00$ & $107,046.00$ & $12,205,939.00$ \\
\hline
\end{tabular}




\begin{tabular}{|c|c|c|c|c|}
\hline \multicolumn{5}{|c|}{$\begin{array}{c}\text { TABLE } 3 \\
\text { Descriptive Statistics for Circulation, Reference, and Instruction for a } \\
\text { Sample of 99 ARL Libraries }\end{array}$} \\
\hline & & $\begin{array}{c}\text { Initial } \\
\text { Circulation } \\
\text { Transactions } \\
\text {-Missing } \\
\text { Values Replaced } \\
\text { with SMEAN } \\
\end{array}$ & $\begin{array}{c}\text { Reference } \\
\text { Transactions - } \\
\text { Missing Values } \\
\text { Replaced with } \\
\text { SMEAN }\end{array}$ & $\begin{array}{c}\text { Participants } \\
\text { in Group } \\
\text { Presentations- } \\
\text { Missing Values } \\
\text { Replaced with } \\
\text { SMEAN } \\
\end{array}$ \\
\hline \multirow[t]{2}{*}{$\mathrm{N}$} & Valid & 99 & 99 & 99 \\
\hline & Missing & 0 & 0 & 0 \\
\hline Mean & & $328,542.93$ & $86,301.99$ & $15,562.34$ \\
\hline Median & & $279,606.00$ & $76,782.00$ & $13,468.00$ \\
\hline Mode & & 32,8543 & 86,302 & 15,562 \\
\hline Std. Deviation & & $219,672.25$ & $52,409.67$ & $8,909.14$ \\
\hline Skewness & & 3.96 & 1.40 & 1.46 \\
\hline Std. Error of Skewness & & .24 & .24 & .24 \\
\hline Kurtosis & & 24.68 & 2.00 & 3.64 \\
\hline Std. Error of Kurtosis & & .48 & .48 & .48 \\
\hline Range & & $1,811,869$ & 262,509 & 52,852 \\
\hline Minimum & & 65,896 & 11,229 & 2,369 \\
\hline Maximum & & $1,877,765$ & 273,738 & 55,221 \\
\hline \multirow[t]{3}{*}{ Percentiles } & 25 & $202,560.00$ & $51,802.00$ & $9,378.00$ \\
\hline & 50 & $279,606.00$ & $76,782.00$ & $13,468.00$ \\
\hline & 75 & $363,766.00$ & $101,963.00$ & $19,089.00$ \\
\hline
\end{tabular}

is $4,240,929$ volumes with a standard deviation of 2,405,886 volumes. The smallest library has just over 2 million volumes, while the largest library has almost 16 million volumes. This pattern continues for volumes added per year, expenditures, initial circulation, reference, and participants receiving instruction. See tables 2 and 3 for details.

As indicated in the literature review, multiple studies found that race/ethnicity and SES had a significant impact on student persistence in college. Some studies also found a significant impact based on gender. Therefore, we decided to control for these variables. We found that there are large differences in full-time minority student enrollment at ARL institutions. Asian-American, Black, Hispanic, and American Indian students all have a kurtosis of 3 or more, indicating steep differences. For SES, we used the percentage of full-time students receiving need-based financial aid as an indicator. We suspect that financial aid is an imperfect indicator because, in addition to reflecting need, it also is designed to alleviate economic inequality. There is minimal difference between male and female students in the ARL institutions. See tables 4 and 5 for details.

We performed a linear regression of each independent variable on RET and then on GRAD to examine the $\mathrm{R}^{2}$ (the coefficient of determination) and the statistical significance. We then looked at the raw residuals for each regression to determine if the assumptions underlying the linear statistical model would hold. One assumption is that the distribution 
of the standardized residuals is normal. In this sample, all distributions are normal. We also examined the standardized residual scatterplots to determine if there was a systematic relationship left over. For each library variable, we found clusters instead of random scatter. We therefore transformed the $\mathrm{X}$ by taking its $\log 10$ and the plots became more random. We performed the linear regression again using the $\log 10$ for each library variable. For each control variable, we found no patterns in the standardized residual scatterplots.

We found that there was a statistically significant relationship between each pair of variables except for the independent variable of REF on RET and REF on GRAD and the control variable of GEN-
DER (combining MALE and FEMALE) on RET and GENDER on GRAD. We can therefore reject the null hypothesis that there is no relationship between RET and each of the independent variables LG10PROFPCT, LG10WAGETOT, LG10VOLTOT, LG10VOLADD, LG10EXPTOT, LG10CIRC, and LG10CLASSPCT, and the control variables RACE (combining ASIAN, BLACK, HISPANIC, INDIAN, and WHITE) and FINAID in the population from which this sample was drawn. We fail to reject the null hypothesis that there is no relationship between RET and the independent variable LG10REF and the control variable GENDER; failing to reject the null hypothesis means that we cannot draw a conclusion about the relationship between these variables.

\begin{tabular}{|c|c|c|c|c|c|c|}
\hline \multicolumn{7}{|c|}{$\begin{array}{c}\text { TABLE } 4 \\
\text { Descriptive Statistics for Race/Ethnicity for a Sample of 99 ARL Institutions }\end{array}$} \\
\hline & & $\begin{array}{c}\text { Full-Time } \\
\text { Asian } \\
\text { American } \\
\text { Students }\end{array}$ & $\begin{array}{c}\text { Full- } \\
\text { Time } \\
\text { Black } \\
\text { Students }\end{array}$ & $\begin{array}{c}\text { Full- } \\
\text { Time } \\
\text { Hispanic } \\
\text { Students }\end{array}$ & $\begin{array}{l}\text { Full-Time } \\
\text { American } \\
\text { Indian } \\
\text { Students }\end{array}$ & $\begin{array}{c}\text { Full-Time } \\
\text { White } \\
\text { Students }\end{array}$ \\
\hline \multirow[t]{2}{*}{$\mathrm{N}$} & Valid & 99 & 99 & 99 & 99 & 99 \\
\hline & Missing & 0 & 0 & 0 & 0 & 0 \\
\hline Mean & & $2,298.74$ & $1,327.51$ & $1,338.76$ & 157.23 & $14,006.78$ \\
\hline Median & & $1,293.00$ & $1,058.00$ & 746.00 & 81.00 & $13,917.00$ \\
\hline Mode & & $184^{\mathrm{a}}$ & 1358 & 406 & $33^{\mathrm{a}}$ & $83^{\mathrm{a}}$ \\
\hline Std. Deviation & & $2,543.14$ & $1,039.68$ & $1,377.21$ & 245.28 & $7,610.26$ \\
\hline Skewness & & 2.15 & 1.97 & 1.87 & 4.24 & .59 \\
\hline $\begin{array}{l}\text { Std. Error of } \\
\text { Skewness }\end{array}$ & & .24 & .24 & .24 & .24 & .24 \\
\hline Kurtosis & & 4.26 & 5.60 & 3.13 & 20.01 & -.26 \\
\hline $\begin{array}{l}\text { Std. Error of } \\
\text { Kurtosis }\end{array}$ & & .48 & .48 & .48 & .48 & .48 \\
\hline Range & & 11,508 & 6,288 & 6,711 & 1,607 & 34,090 \\
\hline Minimum & & 184 & 160 & 84 & 13 & 83 \\
\hline Maximum & & 11,692 & 6,448 & 6,795 & 1,620 & 34,173 \\
\hline \multirow[t]{3}{*}{ Percentiles } & 25 & 707.00 & 615.00 & 474.00 & 50.00 & $8,084.00$ \\
\hline & 50 & $1,293.00$ & $1,058.00$ & 746.00 & 81.00 & $13,917.00$ \\
\hline & 75 & $2,659.00$ & $1,643.00$ & $1,514.00$ & 161.00 & $18,266.00$ \\
\hline
\end{tabular}




\begin{tabular}{|l|l|r|r|r|}
\hline \multicolumn{5}{|c|}{$\begin{array}{c}\text { TABLE 5 } \\
\text { Descriptive Statistics for Gender and Financial Aid for a Sample of 99 ARL } \\
\text { Institutions }\end{array}$} \\
\hline \multicolumn{2}{|c|}{} & $\begin{array}{c}\text { Percent } \\
\text { Receiving } \\
\text { Financial Aid }\end{array}$ & $\begin{array}{c}\text { Full-Time Male } \\
\text { Students }\end{array}$ & $\begin{array}{c}\text { Full-Time } \\
\text { Female } \\
\text { Students }\end{array}$ \\
\hline \multirow{2}{*}{ N } & Valid & 98 & 99 & 99 \\
\cline { 2 - 6 } & Missing & 1 & 0 & 0 \\
\hline Mean & & 72.786 & $10,863.26$ & $11,186.31$ \\
\hline Median & & 73.00 & $10,020.00$ & $10,490.00$ \\
\hline Mode & & 73.00 & $2,774^{\mathrm{a}}$ & $2,133^{\mathrm{a}}$ \\
\hline Std. Deviation & & 12.24 & $4,791.53$ & $4,912.40$ \\
\hline Skewness & & .14 & .66 & .45 \\
\hline Std. Error of Skewness & & .24 & .24 & .24 \\
\hline Kurtosis & & -.87 & .07 & -.27 \\
\hline Std. Error of Kurtosis & & .48 & .48 & .48 \\
\hline Range & & 47.00 & 20,650 & 21,458 \\
\hline Minimum & & 49.00 & 2,774 & 2,133 \\
\hline Maximum & & 96.00 & 23,424 & 23,591 \\
\hline Percentiles & & 62.75 & $7,334.00$ & $7,898.00$ \\
\cline { 2 - 6 } & 50 & 73.00 & $10,020.00$ & $10,490.00$ \\
\cline { 2 - 6 } & 75 & $13,518.00$ & $14,550.00$ \\
\hline a Multiple modes exist. The smallest value is shown & & \\
\hline
\end{tabular}

The same holds true for GRAD. We can reject the null hypothesis that there is no relationship between GRAD and each of the independent variables LG10PROFPCT, LG10WAGETOT, LG10VOLTOT, LG10VOLADD, LG10EXPTOT, LG10CIRC, and LG10CLASSPCT, and the control variables RACE and FINAID in the population from which this sample was drawn; rejecting the null hypothesis means that it is probable that there is a relationship between these variables. We fail to reject the null hypothesis that there is no relationship between GRAD and the independent variable LG10REF and the control variable GENDER.

To construct our regression model, we analyzed how the variables related to each other by estimating both simple and partial correlations for all of our variables.
The simple correlations are presented in the estimated correlation matrix in tables 6 and 7.

The partial correlation controlling for gender, race/ethnicity, and financial aid is presented in the estimated correlation matrix in table 8 .

Retention and graduation rates are highly correlated (.945 simple correlation, .934 partial correlation), indicating a high probability that the measures are related. This makes sense, since both measures are indicators of student persistence (table 6).

Table 6 shows that the strongest correlation with retention is Log 10 PROFPCT (.597). A more moderate correlation is with Log 10 WAGETOT (.517). Weaker correlations include Log 10 EXPTOT (.484), Log 10 VOLTOT (.464), Log 10 VOLADD (.366), Log 10 of CLASSPCT (.299), and Log 10 CIRC (.276). We there- 


\begin{tabular}{|l|c|c|c|c|c|c|c|c|c|c|}
\hline \multicolumn{8}{|c|}{ TABLE 6 } \\
\hline \multicolumn{19}{|c|}{ Simple Correlation Matrix for Library Variables, Retention, and Graduation } \\
\hline
\end{tabular}

TABLE 7

Simple Correlation Matrix for Control Variables, Retention, and Graduation

\begin{tabular}{|c|c|c|c|c|c|c|c|c|c|c|}
\hline & RET & GRAD & ASIAN & BLACK & HISPANIC & INDIAN & WHITE & FINAID & MEN & WOMEN \\
\hline RET & 1 & & & & & & & & & \\
\hline GRAD & $.945^{* *}$ & 1 & & & & & & & & \\
\hline ASIAN & $.216^{*}$ & .173 & 1 & & & & & & & \\
\hline BLACK & $-.210^{*}$ & $-.287 * *$ & -.019 & 1 & & & & & & \\
\hline HISPANIC & -.009 & -.073 & $.514 * *$ & .095 & 1 & & & & & \\
\hline INDIAN & $-.286^{* *}$ & $-.272 * *$ & -.027 & -.091 & $.255^{*}$ & 1 & & & & \\
\hline WHITE & -.188 & $-.231 *$ & -.047 & $.265 * *$ & $.220^{*}$ & $.200 *$ & 1 & & & \\
\hline FINAID & $-.408 * *$ & $-.403 * *$ & $-.217 *$ & $.316 * *$ & .077 & .155 & $.285^{* *}$ & 1 & & \\
\hline MEN & -.045 & -.106 & $.348 * *$ & $.291 * *$ & $.487 * *$ & .182 & $.874 * *$ & .171 & 1 & \\
\hline WOMEN & -.079 & -.151 & $.405 * *$ & $.391 * *$ & $.544 * *$ & .192 & $.832 * *$ & $.212^{*}$ & $.909 * *$ & 1 \\
\hline
\end{tabular}


fore reject the null hypothesis that there is no relationship between these variables in the population. There is no statistically significant correlation with Log $10 \mathrm{REF}$, so we fail to reject the null hypothesis that there is no relationship between $\log 10$ REF and RET in the population.

The correlations for GRAD parallel the correlations for RET. Once again, table 6 shows that the strongest correlation with graduation is also Log 10 PROFPCT (.598). The more moderate correlations are with Log 10 WAGETOT (.519) and EXPTOT (.508), and the weaker correlations include Log 10 VOLTOT (.484), Log 10 VOLADD (.382), Log 10 CIRC (.310) and CLASSPCT (.254). We therefore reject the null hypothesis that there is no relationship between these variables in the population. As with RET, there is no statistically significant correlation with Log 10 REF, so we fail to reject the null hypothesis that there is no relationship between these variables in the population.
Simple correlations between RET and GRAD and the control variables reveal weak but statistically significant correlations with race/ethnicity and FINAID (see table 7). We therefore reject the null hypothesis that there is no relationship between these variables in the population. There is no statistically significant correlation between RET or GRAD and gender (see table 7). We fail to reject the null hypothesis that there is no relationship between these variables in the population. Based on the lack of correlation, we decided to remove the independent variable of Log 10 REF and the control variable of gender from the model.

We then examined the correlations between independent variables. Because there is high collinearity between similar variables, we decided to include in our model only one variable each to indicate staff, collections, use, and service. For staff, we selected Log 10 PROFPCT and for collections we selected Log 10 EXPTOT

\begin{tabular}{|l|c|c|c|c|c|c|c|c|c|c|}
\hline \multicolumn{8}{|c|}{ TABLE 8 } \\
\multicolumn{8}{|c|}{ Partial Correlation Matrix for Library Variables, Retention, and Graduation } \\
Controlling for Race/Ethnicity and Financial Aid \\
\hline
\end{tabular}


because of their higher correlation with RET and GRAD. We retained Log 10 CIRC for use and Log 10 CLASSPCT for service.

We fit two models, one each for RET and GRAD. We started with RET. We decided to first build a baseline control model containing all of the control variables before adding question predictors and checking for interactions, RÊT $=103$ $+.000 *$ ASIAN $-.001 *$ BLACK $+.000 *$ HISPANIC $-.007^{*}$ INDIAN $-.000^{*}$ WHITE -
$.173^{*}$ FINAID. This model tells us that 25 percent of the fall-to-fall retention can be explained by the variation in race/ethnicity and financial aid. The relationship is statistically significant $(\mathrm{F}=5.087, p<.000)$.

We then fitted our second model by conducting a simple regression model, $\mathrm{RE} T=99+18.123^{*}$ LG10PROFPCT + $.001 *$ ASIAN $+.000^{*}$ BLACK $+.000^{*}$ HIS PANIC $-.005^{*}$ INDIAN $+.000^{*}$ WHITE $-.087^{*}$ FINAID. This model tells us that

\begin{tabular}{|c|c|c|c|c|c|}
\hline $\begin{array}{l}\text { Nested taxonomy } \\
\text { is predicted by li } \\
\text { expenditures on } \\
\text { receiving library } \\
\text { students receivin }\end{array}$ & $\begin{array}{l}\text { ff fitted mul } \\
\text { rary percent } \\
\text { llections, in } \\
\text { nstruction, c } \\
\text { financial aic }\end{array}$ & $\begin{array}{l}\text { TABLE } \\
\text { iple regress } \\
\text { ge of profe } \\
\text { ial circulat } \\
\text { ntrolling fo }\end{array}$ & $\begin{array}{l}\text { on models i } \\
\text { sional staff } \\
\text { on, and per } \\
\text { r race/ethni }\end{array}$ & $\begin{array}{l}\text { which ret } \\
\text { per studen } \\
\text { entage of s } \\
\text { ity and pe }\end{array}$ & $\begin{array}{l}\text { ntion } \\
\text { total } \\
\text { udents } \\
\text { centage of }\end{array}$ \\
\hline Predictor & & & Model & & \\
\hline & M1 & M2 & M3 & M4 & M5 \\
\hline Intercept & $\begin{array}{c}103.044^{* * *} \\
4.261 \\
\end{array}$ & $\begin{array}{c}99.196^{* * * *} \\
3.481 \\
\end{array}$ & $\begin{array}{c}69.786^{*} \\
33.699 \\
\end{array}$ & $\begin{array}{c}71.640 \sim \\
36.710 \\
\end{array}$ & $\begin{array}{c}68.636 \sim \\
37.314 \\
\end{array}$ \\
\hline LG10PROFPCT & & $\begin{array}{c}18.123 * * * \\
2.570\end{array}$ & $\begin{array}{c}15.744 * * * \\
3.738\end{array}$ & $\begin{array}{c}15.859 * * * \\
3.859\end{array}$ & $\begin{array}{c}15.119 * * * \\
4.128\end{array}$ \\
\hline LG10EXPTOT & & & $\begin{array}{l}4.180 \\
4.764 \\
\end{array}$ & $\begin{array}{l}4.292 \\
4.866 \\
\end{array}$ & $\begin{array}{l}4.665 \\
4.939 \\
\end{array}$ \\
\hline LG10CIRC & & & & $\begin{array}{r}.488 \\
3.713 \\
\end{array}$ & $\begin{array}{r}-.993 \\
3.854 \\
\end{array}$ \\
\hline LG10CLASSPCT & & & & & $\begin{array}{l}1.520 \\
2.927 \\
\end{array}$ \\
\hline ASIAN & $\begin{array}{l}.000 \\
.000 \\
\end{array}$ & $\begin{array}{l}.001^{*} \\
.000 \\
\end{array}$ & $\begin{array}{l}.000 \sim \\
.000 \\
\end{array}$ & $\begin{array}{l}.000 \\
.000 \\
\end{array}$ & $\begin{array}{l}.000 \sim \\
.000 \\
\end{array}$ \\
\hline BLACK & $\begin{array}{c}-.001 \\
.001 \\
\end{array}$ & $\begin{array}{l}.000 \\
.001 \\
\end{array}$ & $\begin{array}{l}.000 \\
.001 \\
\end{array}$ & $\begin{array}{l}.000 \\
.001 \\
\end{array}$ & $\begin{array}{l}.000 \\
.001 \\
\end{array}$ \\
\hline HISPANIC & $\begin{array}{l}.000 \\
.001 \\
\end{array}$ & $\begin{array}{l}.000 \\
.000 \\
\end{array}$ & $\begin{array}{l}.000 \\
.000 \\
\end{array}$ & $\begin{array}{l}.000 \\
.000 \\
\end{array}$ & $\begin{array}{l}.000 \\
.001 \\
\end{array}$ \\
\hline INDIAN & $\begin{array}{c}-.007 * \\
.003 \\
\end{array}$ & $\begin{array}{c}-.005^{*} \\
.002 \\
\end{array}$ & $\begin{array}{c}-.005^{*} \\
.002 \\
\end{array}$ & $\begin{array}{c}-.005^{*} \\
.002 \\
\end{array}$ & $\begin{array}{c}-.005^{*} \\
.002 \\
\end{array}$ \\
\hline WHITE & $\begin{array}{c}.000 \dagger \\
.000 \\
\end{array}$ & $\begin{array}{c}.000^{* *} \\
.000 \\
\end{array}$ & $\begin{array}{l}.000 \\
.000 \\
\end{array}$ & $\begin{array}{l}.000 \\
.000 \\
\end{array}$ & $\begin{array}{l}.000 \\
.000 \\
\end{array}$ \\
\hline FINAID & $\begin{array}{c}-.173 * * \\
.060\end{array}$ & $\begin{array}{c}-.087 \sim \\
.050\end{array}$ & $\begin{array}{c}-.082 \\
.050 \\
\end{array}$ & $\begin{array}{c}-.083 \\
.051 \\
\end{array}$ & $\begin{array}{c}-.081 \\
.052 \\
\end{array}$ \\
\hline $\mathrm{R}^{2}$ & .251 & .518 & .522 & .522 & .523 \\
\hline Error $\mathrm{df}$ & 91 & 90 & 89 & 88 & 87 \\
\hline
\end{tabular}




\section{TABLE 10}

Nested taxonomy of fitted multiple regression models in which graduation is predicted by library percentage of professional staff per student, total expenditures on collections, initial circulation, and percentage of students receiving library instruction, controlling for race/ethnicity and percentage of students receiving financial aid.

\begin{tabular}{|c|c|c|c|c|c|}
\hline \multirow[t]{2}{*}{ Predictor } & \multicolumn{5}{|c|}{ Model } \\
\hline & M1 & M2 & M3 & M4 & M5 \\
\hline Intercept & $\begin{array}{c}103.572 * * * \\
9.068\end{array}$ & $\begin{array}{c}95.367 * * * \\
7.403 \\
\end{array}$ & $\begin{array}{c}4.565 \\
71.308 \\
\end{array}$ & $\begin{array}{l}-2.910 \\
77.659 \\
\end{array}$ & $\begin{array}{c}-.893 \\
79.048 \\
\end{array}$ \\
\hline LG10PROFPCT & & $\begin{array}{c}38.640 * * * \\
5.465\end{array}$ & $\begin{array}{c}31.295 * * * \\
7.910\end{array}$ & $\begin{array}{c}30.834 * * * \\
8.163\end{array}$ & $\begin{array}{c}31.331 * * * \\
8.745\end{array}$ \\
\hline LG10EXPTOT & & & $\begin{array}{l}12.906 \\
10.081 \\
\end{array}$ & $\begin{array}{l}12.453 \\
10.294 \\
\end{array}$ & $\begin{array}{l}12.203 \\
10.462 \\
\end{array}$ \\
\hline LG10CIRC & & & & $\begin{array}{l}1.966 \\
7.856\end{array}$ & $\begin{array}{l}2.306 \\
8.164\end{array}$ \\
\hline LG10CLASSPCT & & & & & $\begin{array}{c}-1.021 \\
6.200 \\
\end{array}$ \\
\hline ASIAN & $\begin{array}{l}.001 \\
.001 \\
\end{array}$ & $\begin{array}{l}.001 \sim \\
.001 \\
\end{array}$ & $\begin{array}{l}.001 \\
.001 \\
\end{array}$ & $\begin{array}{l}.001 \\
.001 \\
\end{array}$ & $\begin{array}{l}.001 \\
.001 \\
\end{array}$ \\
\hline BLACK & $\begin{array}{c}-.003^{*} \\
.001\end{array}$ & $\begin{array}{c}-.002 \sim \\
.001 \\
\end{array}$ & $\begin{array}{l}-.002 \sim \\
.001 \\
\end{array}$ & $\begin{array}{c}-.002 \sim \\
.001\end{array}$ & $\begin{array}{c}-.002 \sim \\
.001\end{array}$ \\
\hline HISPANIC & $\begin{array}{l}.000 \\
.001 \\
\end{array}$ & $\begin{array}{l}.000 \\
.001 \\
\end{array}$ & $\begin{array}{l}.000 \dagger \\
.001\end{array}$ & $\begin{array}{l}.000 \dagger \\
.001\end{array}$ & $\begin{array}{l}.000 \dagger \\
.001\end{array}$ \\
\hline INDIAN & $\begin{array}{c}-.015^{*} \\
.006\end{array}$ & $\begin{array}{c}-.009 \sim \\
.005\end{array}$ & $\begin{array}{l}-.010^{*} \\
.005\end{array}$ & $\begin{array}{l}-.010^{*} \\
.005\end{array}$ & $\begin{array}{c}-.010 \sim \\
.005\end{array}$ \\
\hline WHITE & $\begin{array}{c}.000 \dagger \\
.000 \\
\end{array}$ & $\begin{array}{l}.000 * \\
.000 \\
\end{array}$ & $\begin{array}{l}.000 \\
.000 \\
\end{array}$ & $\begin{array}{l}.000 \\
.000 \\
\end{array}$ & $\begin{array}{l}.000 \\
.000 \\
\end{array}$ \\
\hline FINAID & $\begin{array}{c}-.327^{*} \\
.127 \\
\end{array}$ & $\begin{array}{c}-.144 \\
.106 \\
\end{array}$ & $\begin{array}{c}-.128 \\
.106 \\
\end{array}$ & $\begin{array}{c}-.123 \\
.108 \\
\end{array}$ & $\begin{array}{l}-.125 \\
.109 \\
\end{array}$ \\
\hline $\mathrm{R}^{2}$ & .263 & .526 & .535 & .535 & .535 \\
\hline Error df & 91 & 90 & 89 & 88 & 87 \\
\hline
\end{tabular}

52 percent of the fall-to-fall retention rate can be explained by LG10PROFPCT when controlling for race/ethnicity and financial aid. The relationship is statistically significant $(\mathrm{F}=13.799, p<.000)$.

In an attempt to explain the remaining variation in retention, we constructed additional multiple regression models by adding the variables LG10EXPTOT, LG10CIRC, and LG10CLASSPCT one at a time. See table 9 for the nested taxonomy of regression models on retention, which measures the impact of each variable.

Table 9 makes it clear that the only library variable that has a statistically significant impact is LG10PROFPCT. Adding additional library variables in Models 3,4 , and 5 provides no new significant information, which we confirmed by calculating a delta $\mathrm{R}^{2}$ test for the inclusion of the additional variables. We therefore 


\section{TABLE 11}

Comparing models fitted before and after the removal of atypical data points. A series of fitted multiple regression models in which retention is predicted by library percentage of professional staff per student, controlling for race/ethnicity and percentage of students receiving financial aid.

\begin{tabular}{|c|c|c|c|c|c|c|}
\hline \multirow[t]{2}{*}{ Predictor } & \multicolumn{6}{|c|}{ Model } \\
\hline & M2 & $\mathrm{M} 2 \mathrm{~A}$ & M2B & $\mathrm{M} 2 \mathrm{C}$ & M2D & M2E \\
\hline Case Removed & & Case 1 & Case 2 & Case 3 & Case 4 & $\begin{array}{c}\text { Case } 1 \\
\& 4\end{array}$ \\
\hline Intercept & $\begin{array}{c}99.196^{* * *} \\
3.481 \\
\end{array}$ & $\begin{array}{c}100.229 * * * \\
3.300 \\
\end{array}$ & $\begin{array}{c}99.605^{* * *} \\
3.325 \\
\end{array}$ & $\begin{array}{c}99.296^{* * *} \\
3.511 \\
\end{array}$ & $\begin{array}{c}98.062 * * * \\
3.467\end{array}$ & $\begin{array}{c}99.080^{* * * *} \\
3.272\end{array}$ \\
\hline LG10PROFPCT & $\begin{array}{c}18.123 * * * \\
2.570\end{array}$ & $\begin{array}{c}17.056^{* * *} \\
2.446 \\
\end{array}$ & $\begin{array}{c}17.386^{* * * *} \\
2.464\end{array}$ & \begin{tabular}{c|}
$18.084 * * *$ \\
2.585 \\
\end{tabular} & $\begin{array}{c}18.559 * * * \\
2.535\end{array}$ & $\begin{array}{c}17.492^{* * * *} \\
2.402\end{array}$ \\
\hline ASIAN & $\begin{array}{l}.001 * \\
.000\end{array}$ & $\begin{array}{c}.001 * * \\
.000\end{array}$ & $\begin{array}{l}.000 \sim ~ \\
.000\end{array}$ & $\begin{array}{l}.001 * \\
.000\end{array}$ & $\begin{array}{l}.001 * \\
.000\end{array}$ & $\begin{array}{c}.001 * * * \\
.000\end{array}$ \\
\hline BLACK & $\begin{array}{l}.000 \\
.001\end{array}$ & $\begin{array}{c}-.001 \\
.001 \\
\end{array}$ & $\begin{array}{l}.000 \\
.001 \\
\end{array}$ & $\begin{array}{l}.000 \\
.001 \\
\end{array}$ & $\begin{array}{c}-.001 \sim \\
.001\end{array}$ & $\begin{array}{c}-.001^{*} \\
.001\end{array}$ \\
\hline HISPANIC & $\begin{array}{l}.000 \\
.000\end{array}$ & $\begin{array}{l}.000 \dagger \\
.000\end{array}$ & $\begin{array}{l}.000 \\
.000\end{array}$ & $\begin{array}{l}.000 \\
.001\end{array}$ & $\begin{array}{l}.000 \\
.000\end{array}$ & $\begin{array}{l}.000 \dagger \\
.000\end{array}$ \\
\hline INDIAN & $\begin{array}{c}-.005^{*} \\
.002\end{array}$ & $\begin{array}{c}-.005^{*} \\
.002\end{array}$ & $\begin{array}{c}-.005^{*} \\
.002\end{array}$ & $\begin{array}{c}-.006 \sim \\
.003 \\
\end{array}$ & $\begin{array}{c}-.005^{*} \\
.002 \\
\end{array}$ & $\begin{array}{c}-.005^{*} \\
.002 \\
\end{array}$ \\
\hline WHITE & $\begin{array}{c}.000 * * \\
.000\end{array}$ & $\begin{array}{c}.000 * * \\
.000\end{array}$ & $\begin{array}{l}.000^{*} \\
.000\end{array}$ & $\begin{array}{c}.000 * * \\
.000\end{array}$ & $\begin{array}{c}.000 * * \\
.000\end{array}$ & $\begin{array}{c}.000 * * * \\
.000\end{array}$ \\
\hline FINAID & $\begin{array}{c}-.087 \sim \\
.050\end{array}$ & $\begin{array}{c}-.100 \sim \\
.047\end{array}$ & $\begin{array}{c}-.092 \sim \\
.048\end{array}$ & $\begin{array}{c}-.089 \sim \\
.050\end{array}$ & $\begin{array}{c}-.070 \\
.050 \\
\end{array}$ & $\begin{array}{c}-.082 \sim \\
.047\end{array}$ \\
\hline $\mathrm{R}^{2}$ & .518 & .560 & .524 & .507 & .539 & .583 \\
\hline Error df & 90 & 89 & 89 & 89 & 89 & 88 \\
\hline
\end{tabular}

select Model 2 as the most parsimonious and the best fit for RET.

We continued by fitting models to GRAD. Once again, we first built a baseline control model containing all of the control variables before adding question predictors and checked for interactions, GRÂD $=103$ $+.001^{*}$ ASIAN $-.003^{*}$ BLACK $+.000^{*}$ HISPANIC $-.015^{*}$ INDIAN $+.000^{*}$ WHITE $-.327^{*}$ FINAID. This model tells us that 26 percent of the six-year graduation rate can be explained by the variation in race/ethnicity and SES. The relationship is statistically significant $(\mathrm{F}=5.403, p<.000)$.

We then fitted our second model by conducting a simple regression model, GRÂD
$=95+38.640 *$ LG10PROFPCT $+.001 *$ ASIAN $-.002^{*} \mathrm{BLACK}+.000^{*} \mathrm{HISPANIC}-.009^{*} \mathrm{IN}-$ DIAN $+.000^{*}$ WHITE $-.144^{*}$ FINAID. This model tells us that 53 percent of the sixyear graduation rate can be explained by LG10PROFPCT when controlling for race/ ethnicity and financial aid. The relationship is statistically significant ( $\mathrm{F}=14.267, p<.000)$.

As with RET, we attempted to explain the remaining variation in retention by constructing additional multiple regression models, adding the variables LG10EXPTOT, LG10CIRC, and LG10CLASSPCT one at a time. See table 10 for the nested taxonomy of regression models on graduation. 
As with retention, table 10 makes it clear that the only library variable that has a statistically significant impact is LG10PROFPCT. Adding additional library variables in Models 3, 4, and 5 provide no new significant information, which we confirmed by calculating a delta $\mathrm{R}^{2}$ test for the inclusion of the additional variables. We therefore select Model 2 for GRAD as the most parsimonious and the best fit.

We moved forward with Model 2 for both RET and GRAD and tested it to see if there were any unusual or influential cases. We calculated PRESS residuals, HAT statistics, Cook's Distance, and covariance ratio, which are tests that detect atypical data points, helping us find cases that fall well outside the model. By further examining the scatterplots of unstandardized predicted value against standardized residual and case number against studentized deleted residual, centered leverage value, Cook's Distance, and covariance ratio (more tests to detect atypical data points), we found four cases that were extreme on Y. For RET and GRAD we found four cases each, some overlapping, that were extreme on $\mathrm{Y}$.

We refit each model by excluding each institution in turn. We found that the most significant change in effects for both RET and GRAD occurred when two universities were excluded. We therefore refit each model once more by excluding them both. See tables 11 and 12.

\section{TABLE 12}

Comparing models fitted before and after the removal of atypical data points. A series of fitted multiple regression models in which graduation is predicted by library percentage of professional staff per student, controlling for race/ethnicity and percentage of students receiving financial aid.

\begin{tabular}{|l|c|c|c|c|c|c|}
\hline & \multicolumn{6}{|c|}{ Model } \\
\hline Predictor & M2 & M2A & M2B & M2C & M2D & M2E \\
\hline Case Removed & & Case 1 & Case 2 & Case 3 & Case 4 & Case 1 \& 3 \\
\hline Intercept & $95.367 * * *$ & $97.310^{* * *}$ & $95.984^{* * *}$ & $93.573^{* * *}$ & $94.662^{* * *}$ & $95.486^{* * *}$ \\
& 7.403 & 7.119 & 7.428 & 7.448 & 7.269 & 7.147 \\
\hline LG10PROF- & $38.640^{* * *}$ & $36.633^{* * *}$ & $38.400^{* * *}$ & $39.329^{* * *}$ & $41.294^{* * *}$ & $37.326^{* * *}$ \\
PCT & 5.465 & 5.276 & 5.470 & 5.447 & 5.504 & 5.247 \\
\hline ASIAN & $.001 \sim$ & $.002^{* *}$ & $.001 \sim$ & $.001 *$ & $.001^{*}$ & $.002^{* *}$ \\
& .001 & .001 & .001 & .001 & .001 & .001 \\
\hline BLACK & $-.002 \sim$ & $-.002 \sim$ & $-.002 \sim$ & $-.003 *$ & -.002 & $-.004 *$ \\
& .001 & .001 & .001 & .001 & .001 & .001 \\
\hline HISPANIC & .000 & -.001 & .000 & .000 & .000 & .000 \\
& .001 & .001 & .001 & .001 & .001 & .001 \\
\hline INDIAN & $-.009 \sim$ & $-.009 \sim$ & $-.014 *$ & $-.010^{*}$ & $-.009 \sim$ & $-.010^{*}$ \\
& .005 & .005 & .007 & .005 & .005 & .005 \\
\hline WHITE & $.000^{*}$ & $.000^{*}$ & $.000^{*}$ & $.001 * *$ & $.000^{*}$ & $.000^{* *}$ \\
& .000 & .000 & .000 & .000 & .000 & .000 \\
\hline FINAID & -.144 & -.167 & -.152 & -.116 & -.132 & -.140 \\
& .106 & .102 & .106 & .107 & .104 & .102 \\
\hline R ${ }^{2}$ & .526 & .561 & .527 & .537 & .548 & .572 \\
\hline Error df & 90 & 89 & 89 & 89 & 89 & 88 \\
\hline$\sim \mathrm{p}<.10, * \mathrm{p}<.05, * * \mathrm{p}<.01, * * * \mathrm{p}<.001$ & & & & \\
\hline
\end{tabular}


The fitted regression equation for Model 2E of RET is: RÊT $=99+17.492 *$ LG10PROFPCT $+.001 *$ ASIAN $-.001 *$ BLACK $-.005^{*}$ HISPANIC $-.005^{*}$ INDIAN + $.000^{*}$ WHITE $-.082 *$ FINAID.

The fitted regression equation for Model 2E of GRAD is: GRÂD $=95+$ $37.326 *$ LG10PROFPCT $+.002 *$ ASIAN $.004^{*} \mathrm{BLACK}+.000^{*} \mathrm{HISPANIC}-.010^{*} \mathrm{IN}-$ DIAN $+.000^{*}$ WHITE $-.140^{*}$ FINAID.

We plotted a family of lines in which we used the minimum and maximum values of RACE and FINAID on a scatterplot of LG10PROFPCT on RET. We repeated the process with GRAD. See figures 1 and 2 . The family of lines shows the changes in these four variables as a function of retention and graduation.

\section{Discussion}

\section{What Do the Data Tell Us?}

There is a relationship between library professional staffing and retention. LG10PROFPCT has a large impact. Because the regression coefficient for LG10PROFPCT has been log transformed, it has little meaning as a predictor variable. So, to calculate the impact, we used the following equation to find what a change in the ratio of professional library staff will cause in the expected mean retention rate: $\beta_{1}{ }^{*} \log 10$ $(\mathrm{X})$, where $\beta_{1}$ is the regression coefficient and $X$ is the percentage change; 1.1 , for example, indicates an increase in 10 percent. Inserting $\beta_{1}$ and a 10 percent increase in the equation yields RET $=17.492 * \log 10$ $(1.1)=0.724041 \%$. In other words, in the population from which the sample was drawn, a 10 percent increase in the ratio of professional library staff predicts a 0.72 percent increase in retention. The equation for graduation is similar. GRAD $=37.326$ ${ }^{*} \log 10(1.1)=1.545023 \%$. In other words, in the population from which the sample was drawn, a 10 percent increase in the ratio of professional library staff predicts a 1.55 percent increase in retention. It makes sense that the impact is greater on graduation than on retention if professional library staff do indeed have an impact on student success. We would presume that the incremental positive impact would

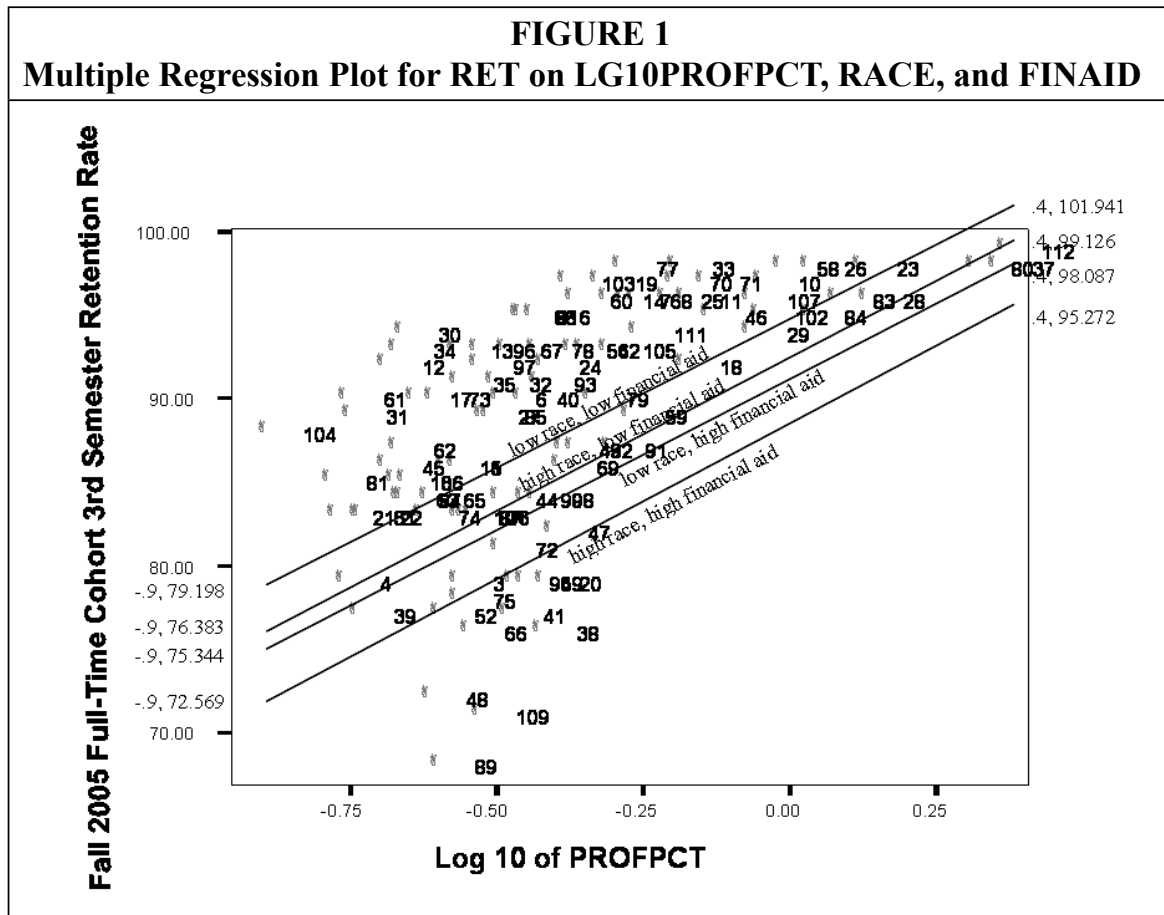




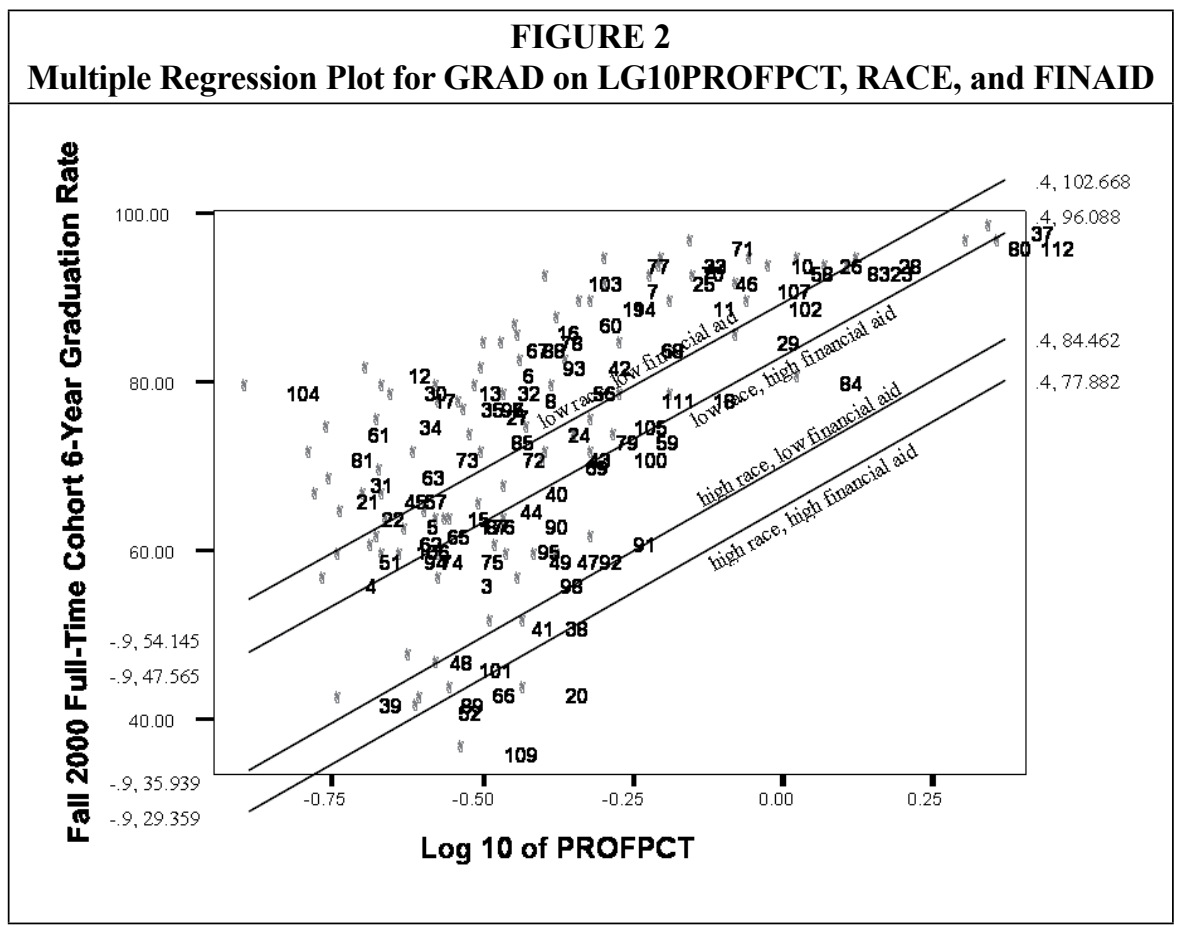

increase over time. Retention is measured from the first year to the second, while graduation is measured over six years.

For both retention and graduation, the relationship is curvilinear. Figure 3 demonstrates that increases in retention and graduation rates disappear gradually. For example, while the first 10 percent increase in the ratio of professional staff to students predicts a .72 percent increase in retention and a 1.55 percent increase in graduation, an additional 10 percent increase only predicts a .67 percent increase in retention and a 1.41 percent increase in graduation. Conversely, decreases in the ratio of professional library staff to students begin gradually and then drop precipitously as nearly all professional library staff are eliminated. See figure 3 for the impact of percentage changes in professional library staff. Note that the percentage increase in ratio is mathematically identical to an increase in the percentage of professional library staff, meaning that increasing professional library staff by 10 percent is the same as increasing the ratio by 10 percent.
Though the race/ethnicity numbers are small, they reflect large populations and are statistically significant (with the exception of HISPANIC). FINAID also has a small but statistically significant impact on retention. There is an even stronger relationship between library staff and graduation. As with retention, race/ ethnicity and FINAID have a statistically significant impact on graduation.

The control variables of race/ethnicity and financial aid make a difference in both fall-to-fall retention and six-year graduation rates. For race/ethnicity, there is a positive relationship with being Asian and a negative relationship with being Black or American Indian. The difference is nine times as big when comparing minimum and maximum values. There is a negative relationship between financial aid and both retention and graduation. The more students receive financial aid, the lower are the retention and graduation rates. For financial aid, the difference is three-fourths again as big. FINAID is statistically significant for RET if we extend 


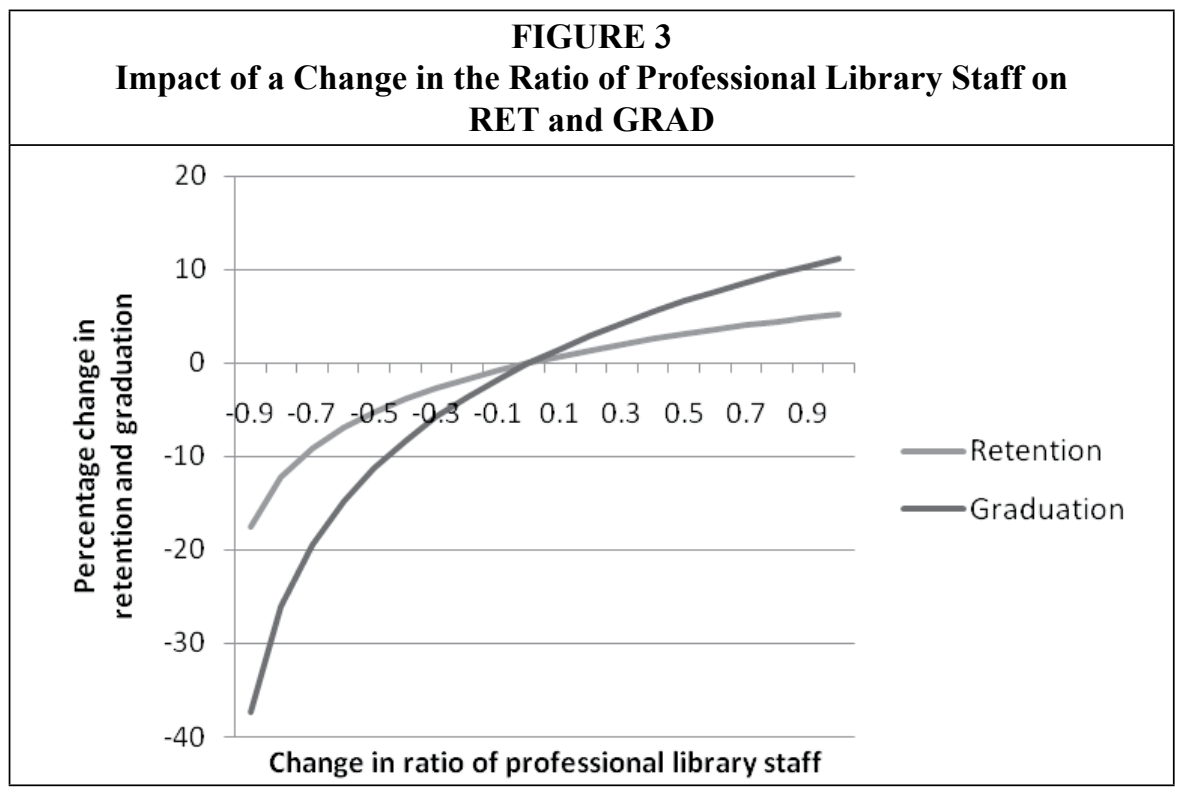

the cutoff for statistical significance to .10 $(t=-1.759, p=.082)$. For GRAD, we would need to extend the cutoff even further $(\mathrm{t}$ $=-1.363, p=.176)$. Ordinarily, we would fail to reject the null hypothesis that there is no relationship between FINAID and GRAD in the population from which our sample is drawn, but we use SES because the literature recommends that it be used.

Combining race/ethnicity and SES provides some interesting findings. As expected, a high level of minority students and a high level of students receiving financial aid leads to low retention and graduation rates; and a low level of minority students and a low level of students receiving financial aid leads to higher retention and graduation rates. For retention, it seems that SES is a somewhat stronger negative indicator of retention than it is for graduation, whereas race/ethnicity is a much stronger negative factor for graduation.

The ratio of professional library staff to full-time students has a larger impact on six-year graduation rates than it does on fall-to-fall retention. The slope is almost twice as steep, confirming our earlier observation that positive professional library staff impact on student success would have an incremental positive increase over time.

\section{Conclusion}

Why would the ratio of professional library staff to full-time students have an impact on student persistence? Why, for example, would a 10 percent increase in professional library staff at an ARL member library predict a .72 percent increase in retention and an even larger 1.55 percent increase in graduation? As librarians, we would like to think that there is a direct impact. Perhaps having more professional library staff helps build collections that connect students better to the knowledge that they need to support their critical thinking. Perhaps having more professional library staff encourages students to use the collections more as they pursue their research. Perhaps having more professional library staff to provide services such as instruction and reference engages students intellectually. We would like to think that such a direct impact exists, but the fitted models we rejected and our own common sense tells us that this is probably not the case.

More likely, there are factors on campus that are collinear with the ratio of professional library staff to full-time students and, more important, we believe that the library has an indirect impact on student persistence. 
Returning to the literature on persistence, there are two major categories of important factors that we see as collinear with ratio of library staff to students. The first category of factors all relate to the elite status of the university. Elite universities in general have a small studentto- faculty ratio; ${ }^{53}$ it makes sense that this same ratio is reflected in the library. Elite universities are more likely to spend more per student ${ }^{54}$ and more on instruction, academic support, and institutional support; the library is most often funded within one of these three categories. In fact, institutional commitment, which includes overall number of faculty and staff on campus - and which presumably includes librarians - is a major factor in college persistence..$^{55} \mathrm{All}$ of these are measures of elite institutions that attract elite students, ${ }^{56}$ who are more likely to persist and graduate from college.

The second category of collinear factors relate to the support offered to students by the university. A welcoming, inclusive environment leads to student persistence, ${ }^{57}$ we believe that more library staff per student provides greater opportunities for welcoming interactions. Students who are engaged are much more likely to persist and graduate from college ${ }^{.58}$ more interactions lead to stronger engagement. One factor of engagement is the provision of learning assistance centers; ${ }^{59}$ it is no stretch of the imagination to include the library as a specialized type of learning assistance center.

Though it is interesting to speculate on collinear factors, we are more intrigued by the indirect impact the library might have on student persistence. Why does the ratio of librarians make a predictive difference when individual input and output measures do not make a difference? In other words, why does the ratio of librarians to students make a difference when the activities that librarians engage in do not make a difference?

We propose using systems thinking as a possible explanation. Systems thinking looks at an organization-not as individ- ual parts - but as people and units and the relationships between them interacting to form a complex whole. Academic libraries are part of a complex social system that includes the university in the environment of the surrounding community. When an institution has more professional staff, they are more likely to interact with the university and its students and faculty, leading to improved information flow, communication, and feedback; and ultimately an organization better adapted to helping students succeed. It is not the individual input measures such as collections and output measures such as use and services that make a difference. Instead, it is the complex interrelationships between these factors and the professional library staff and the students and faculty that make a difference in student persistence. All of these variables are reflections of the library, the university, and the relationship between them.

Our study is an important early step in demonstrating the library's impact on student persistence, but it raises many questions that need to be addressed by future research. Why does the ratio of professional library staff have an impact on student persistence? How many librarians does it take to make a difference? Is there an optimal number of librarians? Why do persistence numbers drop so precipitously as virtually all library professional staff are eliminated? What aspects of the library contribute directly and indirectly to student persistence? Do the findings of this study apply to non-ARL academic libraries? How will administrators at an individual institution measure the impact on persistence of hiring additional librarians? Does the leeway given to ARL libraries in defining professional staff make a difference? Does librarian specialty make a difference? How does the library's role in a larger university system contribute to student persistence? Where does library and librarian quality enter the equation? The answers to these questions will begin to address the specific impact that the academic library has on student success. 


\section{Appendix: Library and Student Success Codebook}

\begin{tabular}{|l|l|}
\hline Dataset & ARL FINAL Variables 2005-06.sav. \\
\hline Overview & $\begin{array}{l}\text { ARL 2005-06 statistics for collections, expenditures, staff, and services } \\
\text { and IPEDS statistics for fall-to-fall persistence, student degree completion, } \\
\text { gender, race/ethnicity, and financial aid. }\end{array}$ \\
\hline Source & $\begin{array}{l}\text { ARL (Association of Research Libraries) and IPEDS (Integrated Postsec- } \\
\text { ondary Education Data System) Annual Statistics for 2005-06. }\end{array}$ \\
\hline $\begin{array}{l}\text { Sample } \\
\text { Size }\end{array}$ & $\begin{array}{l}\text { 99 ARL member academic libraries (excluding non-university ARL mem- } \\
\text { ber libraries). }\end{array}$ \\
\hline Date & 2005-06 data; selected and compiled on March 18, 2008. \\
\hline
\end{tabular}

\begin{tabular}{|c|c|c|c|}
\hline \multicolumn{4}{|c|}{ Structure of the Dataset } \\
\hline Col. \# & Variable Name & Variable Description & $\begin{array}{l}\text { Variable Metric/ } \\
\text { Labels }\end{array}$ \\
\hline 1 & ID & ID Number & Integer \\
\hline 2 & NAME & Institution name & Alphanumeric \\
\hline 3 & RET & $\begin{array}{l}\text { Fall } 2005 \text { full-time cohort 3rd semester } \\
\text { retention rate }\end{array}$ & Percent \\
\hline 4 & GRAD & $\begin{array}{l}\text { Fall } 2000 \text { full-time cohort 6-year gradua- } \\
\text { tion rate }\end{array}$ & Percent \\
\hline 5 & VOLTOT & Volumes in library & Number \\
\hline 6 & LG10VOLTOT & Log 10 of volumes in library & Number \\
\hline 7 & VOLADD & Volumes added & Number \\
\hline 8 & LG10VOLADD & Log 10 of volumes added & Number \\
\hline 9 & EXPTOT & Expenditure on total library materials & $\begin{array}{l}\text { Amount in US } \\
\text { dollars }\end{array}$ \\
\hline 10 & LG10EXPTOT & $\begin{array}{l}\text { Log } 10 \text { of expenditure on total library } \\
\text { materials }\end{array}$ & Number \\
\hline 11 & WAGETOT & Total salaries \& wages & $\begin{array}{l}\text { Amount in US } \\
\text { dollars }\end{array}$ \\
\hline 12 & LG10WAGETOT & Log 10 of total salaries \& wages & Number \\
\hline 13 & FTEPROF & Professional staff (FTE) & Number \\
\hline 14 & PROFPCT & $\begin{array}{l}\text { Ratio of professional library staff to full- } \\
\text { time students }\end{array}$ & Ratio \\
\hline 15 & LG10PROFPCT & $\begin{array}{l}\text { Log } 10 \text { of ratio of professional library staff } \\
\text { to full-time students }\end{array}$ & Number \\
\hline 16 & CLASSATT & Participants in group presentations & Number \\
\hline 17 & CLASSPCT & $\begin{array}{l}\text { Ratio of students receiving library instruc- } \\
\text { tion to full-time students }\end{array}$ & Ratio \\
\hline 18 & LG10CLASPCT & $\begin{array}{l}\text { Log } 10 \text { of ratio of students receiving } \\
\text { library instruction to full-time students }\end{array}$ & Number \\
\hline 19 & REF & Reference transactions & Number \\
\hline
\end{tabular}




\begin{tabular}{|c|c|c|c|}
\hline \multicolumn{4}{|c|}{ Structure of the Dataset } \\
\hline Col. \# & Variable Name & Variable Description & $\begin{array}{c}\text { Variable Metric/ } \\
\text { Labels }\end{array}$ \\
\hline 20 & LG10REF & Log 10 of reference transactions & Number \\
\hline 21 & CIRC & Initial circulation transactions & Number \\
\hline 22 & LG10CIRC & Log 10 of initial circulation transactions & Number \\
\hline 23 & MALE & Number of full-time male students & Number \\
\hline 24 & FEMALE & Number of full-time female students & Number \\
\hline 25 & ASIAN & $\begin{array}{l}\text { Number of full-time Asian American } \\
\text { students }\end{array}$ & Number \\
\hline 26 & BLACK & Number of full-time Black students & Number \\
\hline 27 & HISPANIC & Number of full-time Hispanic students & Number \\
\hline 28 & INDIAN & $\begin{array}{l}\text { Number of full-time American Indian } \\
\text { students }\end{array}$ & Number \\
\hline 29 & WHITE & Number of full-time White students & Number \\
\hline 30 & FINAID & $\begin{array}{l}\text { Percentage of students receiving need- } \\
\text { based financial aid. FINAID serves as an } \\
\text { indicator for SES (socioeconomic status) }\end{array}$ & Percent \\
\hline
\end{tabular}

\section{Notes}

1. R.R. Powell, "Impact Assessment of University Libraries: A Consideration of Issues and Research Methodologies," Library \& Information Science Research 14 (1992): 245-58.

2. Bonnie Gratch-Lindauer, "Defining and Measuring the Library's Impact on Campuswide Outcomes," College \& Research Libraries 59, no. 6 (1993): 546-70.

3. Powell, "Impact Assessment of University Libraries."

4. Gratch-Lindauer, "Defining and Measuring the Library's Impact," 548.

5. Ibid.

6. Kenneth R. Smith, "New Roles and Responsibilities for the University Library: Advancing Student Learning Through Outcomes Assessment," Journal of Library Administration 35, no. 4 (2001): 29-36.

7. Bruce T. Fraser, Charles R. McClure, and Emily H. Leahy, “Toward a Framework for Assessing Library and Institutional Outcomes," portal: Libraries $\mathcal{E}$ the Academy 2, no. 4 (2002): 505-28. See 520 for model.

8. Sharon A. Weiner, "Library Quality and Impact: Is There a Relationship between New Measures and Traditional Measures?" Journal of Academic Librarianship 31, no. 5 (2005): 432-37.

9. George D. Kuh, Piecing Together the Student Success Puzzle: Research, Propositions, and Recommendations, ASHE Higher Education Report; v. 32, no. 5 (San Francisco, Calif.: Wiley Subscription Services at Jossey-Bass, 2007).

10. Ethelene Whitmire, "Development of Critical Thinking Skills: An Analysis of Academic Library Experiences and Other Measurers," College \& Research Libraries 59, no. 3 (1998): 7.

11. Ethelene Whitmire, "Academic Library Performance Measures and Undergraduates' Library Use and Educational Outcomes," Library \& Information Science Research 24, no. 2 (2002): 107-28.

12. Elizabeth M. Mezick, "Return on Investment: Libraries and Student Retention," Journal of Academic Librarianship 33, no. 5 (2007): 561-66.

13. Alexander W. Astin, What Matters In College? Four Critical Years Revisited, The Jossey-Bass Higher and Adult Education Series (San Francisco: Jossey-Bass Publishers, 2001).

14. Ibid.

15. Oscar F. Porter, Undergraduate Completion and Persistence at Four-Year Colleges and Universities: Detailed Findings (Washington, D.C.: National Institute of Independent Colleges and Universities, 1990).

16. Paul A. Murtaugh, Leslie D. Burns, and Jill Schuster, "Predicting the Retention of University 
Students," Research in Higher Education 40 (1999): 355-71.

17. Kevin Carey, A Matter of Degrees Improving Graduation Rates in Four-Year Colleges and Universities (Washington, D.C.: Education Trust, 2004). Available online at www2.edtrust.org/ NR/rdonlyres/11B4283F-104E-4511-B0CA-1D3023231157/0/highered.pdf. [Accessed 19 August 2009].

18. Linda C. Strauss and J. Fredericks Volkwein, "Predictors of Student Commitment at Two-Year and Four-Year Institutions," Journal of Higher Education 75, no. 2 (2004): 203-27.

19. Astin, What Matters in College?

20. Porter, Undergraduate Completion and Persistence.

21. Carey, A Matter of Degrees.

22. Wesley R. Habley and Randy McClanahan, What Works in Student Retention? All Survey Colleges (Iowa City, Ia.: ACT, 2004). Available online at www.act.org/path/postsec/droptables/ pdf/AllColleges.pdf. [Accessed 19 August 2009].

23. Murtaugh, Burns, and Schuster, "Predicting the Retention of University Students."

24. Carey, A Matter of Degrees.

25. Astin, What Matters in College?

26. Clifford Adelman, Principal Indicators of Student Academic Histories in Postsecondary Education, 1972-2000 (Washington, D.C.: Institute of Education Sciences, U.S. Dept. of Education, 2004). Available online at http://purl.access.gpo.gov/GPO/LPS91584. [Accessed 19 August 2009].

27. Astin, What Matters in College?

28. Alberto F. Cabrera, Amaury Nora, and Maria B. Castaneda, "College Persistence," Journal of Higher Education 64, no. 2 (1993): 123-39.

29. Murtaugh, Burns, and Schuster, "Predicting the Retention of University Students."

30. Carey, A Matter of Degrees.

31. Astin, What Matters in College?

32. Habley and McClanahan, "What Works in Student Retention."

33. Astin, "What Matters in College?"

34. Carey, "A Matter of Degrees"

35. Habley and McClanahan, What Works in Student Retention?

36. Strauss and Volkwein, "Predictors of Student Commitment."

37. Vincent Tinto, Leaving College: Rethinking the Causes and Cures of Student Attrition, 2nd ed. (Chicago; London: University of Chicago Press, 1993).

38. Habley and McClanahan, What Works in Student Retention?

39. Carey, A Matter of Degrees.

40. Gary Pike, John Smart, George Kuh, and John Hayek, "Educational Expenditures and Student Engagement: When Does Money Matter?" Research in Higher Education 47 (2006): 847-72.

41. Porter, Undergraduate Completion and Persistence.

42. Habley and McClanahan, What Works in Student Retention?

43. Strauss and Volkwein, "Predictors of Student Commitment."

44. Porter, Undergraduate Completion and Persistence.

45. Adelman, Principal Indicators of Student Academic Histories.

46. Astin, What Matters in College?

47. Carey, A Matter of Degrees.

48. Deborah Faye Carter, "Key Issues in the Persistence of Underrepresented Minority Students," New Directions for Institutional Research 130 (2006): 33-46.

49. Marvin A. Titus, "Understanding College Degree Completion of Students with Low Socioeconomic Status: The Influence of the Institutional Financial Context," Research in Higher Education 47 (2006): 371-98.

50. Association of Research Libraries (ARL), Statement on Qualifications for Membership (1994).

Available online at www.arl.org/arl/membership/qualify.shtml. [Accessed 19 August 2009].

51. Association of Research Libraries (ARL), 2005-2006 Annual Survey of ARL Statistics (2006). Available online at www.arl.org/bm doc/06tables.xls. [Accessed 19 August 2009].

52. National Center for Education Statistics, Integrated Postsecondary Education Data System (IPEDS) (Washington, D.C.: Office of Educational Research and Improvement, U.S. Dept. of Education, 2006).

53. Astin, What Matters in College?

54. Titus, "Understanding College Degree Completion."

55. Cabrera, Nora, and Castaneda, "College Persistence."

56. Adelman, Principal Indicators of Student Academic Histories.

57. Carey, A Matter of Degrees.

58. Tinto, Leaving College.

59. Habley and McClanahan, What Works in Student Retention? 


\section{Brill's Classical Studies Online Resources}

\section{International Aristotle Bibliography}

Presented and Maintained by

Richard Ingardia, St John's University, USA

\begin{tabular}{c|c}
$\begin{array}{c}\text { International } \\
\text { Aristotle }\end{array}$ & brill.nl/iabo \\
Bibliography & $\begin{array}{l}\cdot \text { Published by Brill } \\
\text { since } 2009 \\
\text { •E-ISSN } 1877-0460\end{array}$ \\
\hline
\end{tabular}

Supplementum Epigraphicum Graecum Online

Edited by A. Chaniotis, T. Corsten,

R.S. Stroud and R.A. Tybout

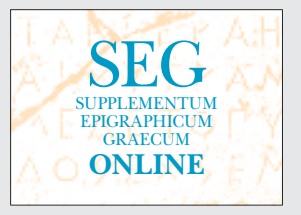

New Pauly Online

Edited by Hubert Cancik

and Helmuth Schneider (Antiquity)

and Manfred Landfester (Classical Tradition)

Managing Editors English Edition:

Christine F. Salazar (Antiquity)

and Francis G. Gentry (Classical Tradition)

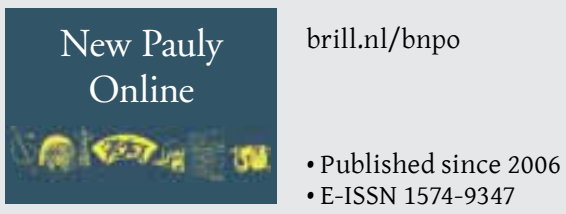

Jacoby Online

\begin{tabular}{|c|}
\hline JACOBY \\
ONLINE \\
\hline BRILL
\end{tabular}

brill.nl/bnjo

- Published since 2007

- E-ISSN 1873-5363

\section{Brill's Classical Studies E-Book Collection}

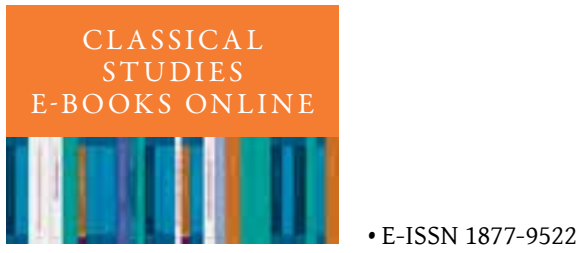

Coverage

Ancient Philosophy, Ancient History, Ancient Religion, Greek and Roman Literature, Epigraphy \& Papyrology, Archeology

Number of titles in this collection

$2007 \quad 2008 \quad 2009 \quad 2010 \quad$ Total

For more information about Brill's Online Resources, send your e-mail to brillonline@brill.nl or brillonline@brillusa.com for customers in the Americas.

B R I L L A 30-day free trial is available to institutions only. 


\title{
Indo-European Etymological Dictionaries Online
}

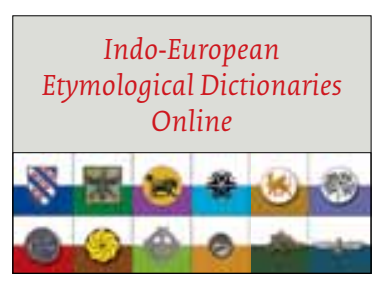

\author{
Editor: Alexander Lubotsky \\ brill.nl/iedo
}

The Indo-European Etymological Dictionaries Online (IED Online) reconstructs the lexicon for the most important languages and language branches of IndoEuropean. It is a rich and voluminous online reference source for historical and general linguists. Dictionaries can be cross-searched, with an advance search for each individual dictionary enabling the user to perform more complex research queries. Each entry is accompanied by grammatical info, meaning(s), etymological commentary, reconstructions, cognates and often extensive bibliographical information. New content will be added on an annual basis.

\section{Linguistic Bibliography Online}

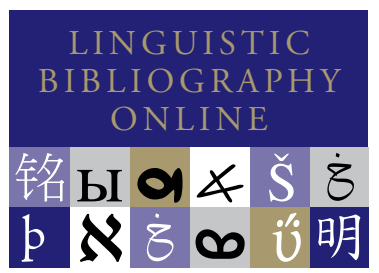

\author{
Edited by Hella Olbertz \\ and Sijmen Tol
}

The Linguistic Bibliography Online is an essential linguistic reference tool that is unique in its field. It provides over 260.000 bibliographical references to scholarly publications in linguistics. It covers all disciplines of theoretical linguistics, both general and language specific, from all geographical areas, including less-known and extinct languages, with particular attention to the many endangered languages of the world. It is by far the most comprehensive bibliography in the field. Up-to-date information is guaranteed by the collaboration of some forty contributing specialists from all over the world. With annually around 20.000 records added, the Linguistic Bibliography remains the standard reference work for every scholar of linguistics.

For a 30-day free trial (institutions only), consortia deals and other pricing options, please send an e-mail to brillonline@brill.nl or brillonline@brillusa.com for customers in the Americas. 